\title{
Özofagus kanserinde palyatif teknikler
}

\section{Palliative techniques in esophageal cancer}

\author{
Atilla Eroğlu*, Yener Aydın \\ Atatürk Üniversitesi, Tıp Fakültesi, Göğüs Cerrahisi Anabilim Dall, Erzurum, Türkiye
}

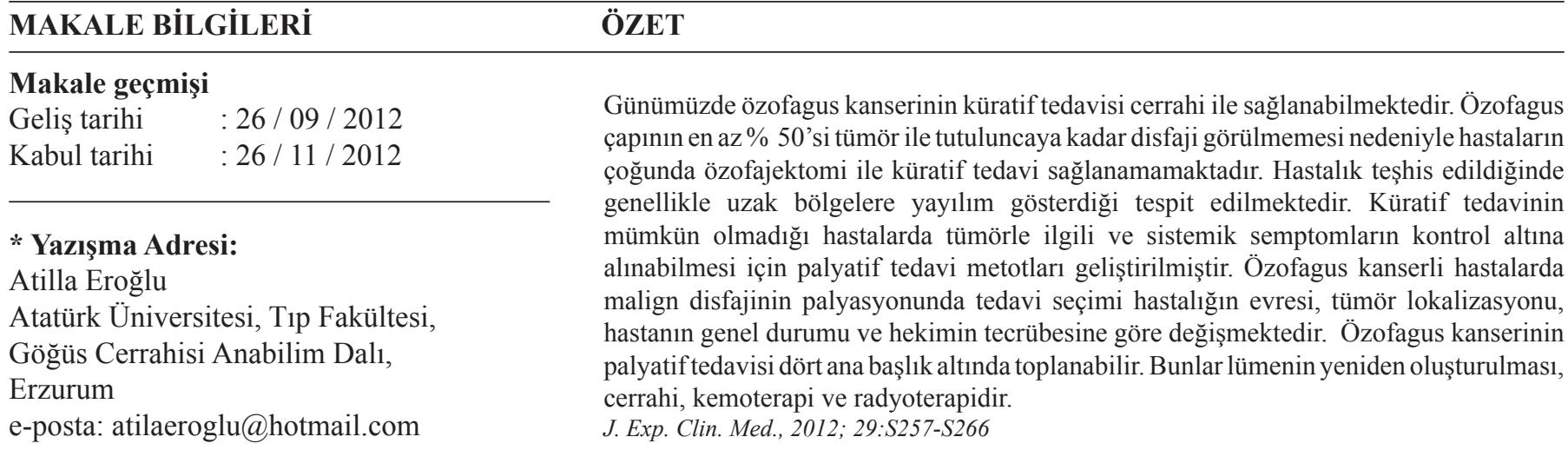

\section{Anahtar Kelimeler:}

Özofagus kanseri

Palyasyon

Stent

Kemoterapi

Radyoterapi

Cerrahi

\section{Keywords:}

Esophageal cancer

Palliation

Stent

Chemotherapy

Radiotherapy

Surgery

\begin{abstract}
Today, curative treatment of esophageal cancer can be achieved by surgery. Dysphagia doesn't seen until tumor diameter reaches at least $50 \%$ of esophagus diameter so curative treatment with esophagectomy can't be provided in most patients. Spreading to remote areas is usually seen when the disease diagnosed. In patients that curative treatment is not possible, palliative tratment methods are used to control tumor associated symptoms and systemic symptoms. Palliative treatment choice of malignant dysphagia in esophageal cancer patients varies according to disease stage, tumor location, general condition of patient, physician's experience. Palliative treatment of esophagus cancer can be grouped under four main headings. These are lumen reconstruction, surgery, chemotherapy and radiotherapy.

J. Exp. Clin. Med., 2012; 29: S257-S266
\end{abstract}

\section{Giriş}

Amerika Birleşik Devletleri'nde özofagus kanserinin yıllık insidansı yaklaşık 14000'dir. Özofagus çapının en az \% 50'si tümör ile tutuluncaya kadar disfaji görülmemesi nedeniyle hastaların çoğunda özofajektomi ile küratif tedavi sağlanamamaktadır (Frenkel ve ark., 2009). Hastalık teşhis edildiğinde genellikle uzak bölgelere yayılım gösterdiği tespit edilmektedir. Disfaji ve kilo kaybı bu hastalarda hayat kalitesini önemli derecede etkilemektedir. Küratif tedavinin mümkün olmadığı hastalarda tümörle ilgili semptomların (disfaji, odinofaji, trakeoözofajiyal fistül ve aspirasyon) ve sistemik semptomların (hiperkalsemi, anoreksi, kusma, kaşeksi gibi) kontrol altına alınabilmesi için palyatif tedavi metotları geliştirilmiştir (Ökten, 2003). Bununla birlikte küratif özofajektominin yüksek riskli olduğu hastalarda palyatif tedavi ile semptomlarda önemli bir rahatlama elde edilmekte ve hayat konforu iyileştirilebilmektedir. Özofagus kanserinin palyatif tedavisi 4 ana başlık altında toplanabilir (Tablo 1) (Ökten, 2003).

\section{Lümenin yeniden oluşturulması \\ I. Ekstrakorporeal entübasyon}

Ekstrakorporeal yolla uygulanır. Geniş lümenli bir tüp ile özofagus darlığı bypass edilir ve pasaj sağlanır. Günümüzde çok nadiren kullanılmaktadır. 


\section{Tablo 1. Özofagus kanserinde palyatif tedavi metotları}

1. Lümenin yeniden oluşturulması

a. Ekstrakorporeal entübasyon

b. Dilatasyon

c. Elektrokoagülasyon (BICAP) tümör mili

d. Hipertermi

e. Laser tedavisi

f. Fotodinamik tedavi

g. Endoprotez yerleştirilmesi

2. Cerrahi tedavi

a. Rezeksiyon

b. Bypass

c. Gastrostomi ve özofagostomi

3. Kemoterapi

4. Radyoterapi

\section{Dilatasyon}

Basit tekrarlayan özofajiyal dilatasyon yutma yeteneğinde kısa süreliğine rahatlama sağlar. Dilatasyon işlemi palyasyon sağlayan diğer metotların bulunmadığı durumda geçici olarak kullanılır. Semptomlarda rahatlama genellikle birkaç gün veya en fazla birkaç haftadır. Bununla birlikte plastik tüp veya laser ablasyon ile peroral intübasyon öncesi genellikle dilatasyon gereklidir.

Kendiliğinden genişleyebilen metal stent yerleştirilmeden önce seçilmiş çaplarla lümenin yaklaşı $10 \mathrm{~mm}$ dilatasyonu gerekebilir. Bunun için rehber tel gerektirmeyen Maloney bujiler veya rehber tel ile floroskopik kontrol altında Savary bujiler kullanılabilir. Vakaların çoğunda bu işlem genel anesteziye gerek kalmaksızın hafif bir sedasyon ile gerçekleştirilebilir (Korst ve Ginsberg, 2005).

Özofagus kanserli hastalarda tedavi yaklaşımında ilk iş hastanın beslenmesini sağlamak, ağrısını ve psikolojik rahatsızlıklarını gidermektir. Yutulan sıvı ve bazı solid gıdaların geçişi için stenotik özofajiyal lümenin yeterli bir çapa sahip olması gereklidir. Disfajili hastalarda en kısa zamanda peroral dilatasyon gereklidir. Radyoterapi öncesinde, esnasinda veya sonrasında uygun enstrüman ve teknikler kullanıldığında malign striktürün dilatasyon riski minimaldir (Heit ve ark., 1978; Cassidy ve ark., 1981; Boyce ve ark., 1984). Özofagus kanserli hastaların birçoğu radyoterapi almaktadır. Bu hastalarda striktürün dilatasyonu esnasında perforasyon riskine karşı dikkatli olunmalıdır.

Normal özofagus lümeninin fonksiyonel çapı yaklaşık 25 mm'dir. Lümen çapı $13 \mathrm{~mm}$ civarına düştüğünde solid gıda veya düzenli diyete karşı disfaji gelişir. Lümen çapı 18 mm'den düşük olduğunda striktürün karakterine bağlı olarak diyet içerik ve kıvamında değişiklik yapılmalıdır. Daha hafif derecedeki striktürlerde dilatasyon işlemi ciddi striktürlerden daha kolay ve güvenilirdir. Peroral dilatasyon sonucu özofajiyal lümenin açıklığı geçici olmasına rağmen hastaların \% 90'1ndan fazlasında lümen çapı yeterli yutmaya izin verecek derecede genişler (Cassidy ve ark., 1981).

Obstruktif karsinomada özofagus dilatasyonunun riski kabul edilebilir düzeydedir. Heit ve ark. (1978) özofagus kanseri nedeniyle ardışık 26 hastada floroskopi eşliğinde peroral 616 dilatasyon uygulamışlardır. Araştırmacılar, peroral dilatasyon yönteminin başarı oranını \% 92 olarak bildirmişler ve oldukça güvenli bulmuşlardır. Radyoterapi öncesi, esnas1 veya sonrasında major komplikasyon ortaya çıkmamıştır. Genel durumu kötü ve ciddi striktürü bulunan hastalarda dila- tasyon işlemi uygun bir biçimde yapıldığında güvenli olarak bildirilmiştir. Daha büyük bir seride Cassidy ve ark. (1981) radyoterapi öncesi, esnası ve sonrasında 154 hastada toplam 3160 dilatasyon uygulamışlardır. Sadece 3 hastada mortalite bildirdiler. Ölümlerin ikisi perforasyona bağlı idi. Hastaların \% 98'inde ise peroral dilatasyon başarılı bulundu.

Malign striktürlerin çoğu Savary ve Maloney balon dilatatörleri ile birkaç seansta 17 mm'ye kadar güvenli bir şekilde dilate edilebilir (Heit ve ark., 1978).

Hernandez ve ark. (2000) Maloney dilatasyon tekniği ile 142 hastada uyguladıkları 348 dilatasyon işleminde kompleks striktürlerde perforasyon oranında artış tespit etmişlerdir (Hernandez ve ark., 2000). Yüksek perforasyon riski nedeniyle malign striktürlerde rehber tel olmaksızın Maloney dilatasyondan kaçınılmasını tavsiye etmişlerdir.

Dilatasyon işlemi semptomlar rahatlayıncaya kadar günlük olarak yapılmalıdır. İlk direnç esnasında 3 Frencten daha büyük dilatatör itilmemelidir. İşleme bağlı bir miktar kanama genellikle görülmekte olup masif kanama nadirdir. Dilatasyon işleminin en önemli koplikasyonu 1/400-1/1000 oranında görülen perforasyondur (Ökten, 2003). Dilatasyonla elde edilen rahatlama kısa süreli olup 1-2 hafta içinde tekrarlayan dilatasyonlar gerekmektedir (Javle ve ark., 2006).

III. Elektrokoagülasyon-bipolar (BICAP) tümör mili

1980'lerin sonunda özellikle üst özofagusu içeren uzun striktürlerin tedavisinde bipolar elektrokoagülasyon tümör mili (BICAP) kullanılarak yeni bir endoskopik teknik geliştirildi (Fleisher ve ark., 1987). Özofagus kanserinin palyasyonunda son eklenen metotlardan biridir. Yarıçap 6-15 mm arasında değişen zeytin şeklindeki mil bir elektriksel bağlantı dairesini destekler. Elektrik bağlantıları 50 wattlık bir BICAP jeneratörüne bağlı olup zeytinin yüzeyini 360 dereceden 270 dereceye kadar kaplayabilir. Tümör mili yerleştirilerek çalıştırıldığında dokuda lokalize bir 1sı artışı oluşturan elektrik akımı meydana gelir. Böylece dokunun mile değdiği yer koagüle olur.

BICAP tümör mili özellikle servikal bölgedeki tümörlerde etkili olmaktadır. Bu lokalizasyondaki tümörlerin diğer yöntemlere daha az izin vermesi tümör milinin servikal bölgede kullanılabilirliğini arttırmaktadır. Ayrıca laser ve stent yerleştirilmesinin daha az etkili olduğu, düzgün ve incelen lüminal yüzeye sahip tümörlerde iyi bir seçenektir. Bipolar tümör milinin kullanılabilmesi için özofajiyal lümen milin geçişine izin verecek genişlikte olmalıdır. Ayrıca perforasyon riskinden dolayı tümör kalınlığı 5 mm'den kalın olmalıdır. İşlem öncesi bilgisayarlı tomografi ile lokalizasyon belirlenmelidir. Aksi takdirde mildeki ufak bir kayma normal özofagusun ciddi koterizasyonuna yol açabilir. Gerek görülürse tedavi 2-3 gün içinde tekrarlanarak önceki nekrotik yüzey kaldırılıp daha iyi bir doku etkisi oluşması sağlanabilir. Bipolar elektrokoagülasyon tümör mili (BICAP) teknik olarak başarılı bulunmuştur. Bu metotta teknik başarı oranı \% 80 90, fonksiyonel başarı oranı ise \% 70'lerdedir (Johnston ve ark., 1987; Jensen ve ark., 1988; Ökten, 2003). İşlemin major komplikasyonu hemoraji ve fistüldür.

\section{Hipertermi}

Tümör hücrelerinin 1sı enerjisine hassas olması esasına dayalı olarak geliştirilen bir metottur. Isı enerjisi tümöre tatbik edilir. Radyo dalgaları ile ısı veren bir prob özofagusa yerleş- 
tirilerek yapılır. Bazı çalışmalarda kemoterapi ve radyoterapi ile kombine kullanılmıştır. Eş zamanlı olarak radyoterapi ve hipertermi kombinasyonunda anti-tümör etkinin maksimum olduğu bildirilmiştir (Overgaard, 1980; Overgaard, 1987). İn vivo ve in vitro deneylerde etkinin 2,5-3 kat arttığ 1 tespit edilmiştir. Bununla birlikte tümör ve normal dokuya radyasyon verilip ısıtıldığında normal doku sensitivitesinde artış olur (Overgaard, 1987).

\section{Lazer tedavisi}

Obstruktif özofajiyal kanserde transendoskopik laser tedavisi ilk olarak 1982'de Neodymiumytrium-aluminumgarret (Nd: YAG) laser olarak tanımlanmıştır (Fleischer ve ark., 1982). Laser tedavisi sonrası, stent yerleştirilmesine göre disfajideki rahatlama daha azdır. Laser ile disfajide en çok rahatlama tedavisi sonrasındaki birkaç günde gözlenir. Ancak disfaji yavaş yavaş artar ve genellikle her 4-6 haftada bir tekrarlayan seanslar gerektirir.

Transendoskopik obstruktif intralüminal kanserin tedavisinde laser diğer metotlardan göreceli olarak daha güvenli olmasına rağmen disfajinin palyasyonu genellikle geçicidir. $\mathrm{Bu}$ metod diğer palyatif metodlara göre daha fazla değerlendirilmiştir (Fleischer ve ark., 1982; Loizou ve ark., 1991; Cottier ve ark., 1997). Laser tedavisinin en büyük başarısı polipoid veya büyük intralüminal oklüzyona yol açan lezyonlarda görülmektedir. Proksimal veya özofagogastrik bileşkedeki ve uzun segmentli lezyonlarda laser tedavisi yüksek risk taşıyıp daha az etkiye sahiptir. Subepitelyal metastazı olan, uzun segmenti tutan ve özofagorespiratuar fistülü (ÖRF) olan hastalarda laser tedavisi kontrendikedir.

Ell ve ark. (1986) özofagus kanserli 816 hastada laser tedavisinde başarı oranını \% 83 olarak bildirmişlerdir. Bu çalışmada perforasyon oranı \% 2,1 ve işlemle ilişkili mortalite oranı \% 1 idi. Daha sonra çok merkezli bir çalışmada perforasyon oranı \% 7 olarak bildirildi (Lightdale ve ark., 1995). Bu tedavi disfajinin palyasyonunda iyi sonuçlar sağlamasına rağmen olguların \% 4-9'unda ciddi komplikasyonlar görülebilmektedir (Bisgaard ve ark., 1997).

\section{Fotodinamik tedavi (FDT)}

Hematoporfirin deriveleri verilerek malign tümör hücrelerinin laser 1şınlarına fotosensitivitesini arttırma yöntemidir. Deri, mesane, rektal ve pulmoner tümörlerde bu metot kullanılmıştır. Endoskopik olarak enjekte edilen hematoporfirin deriveleri tümör içinde depolanarak laser ışını ile aktive olur. Böylece tekli oksijen atomlarının yapımı artarak tümörün mikrovasküler yapısı tahrip edilir. Sonuçta iskemiye bağlı olarak tümör dokusunun ölümü gerçekleşir. Birçok çalışmada bu teknikle yutma fonksiyonunun yeniden sağlanmasında \% 90 gibi büyük bir başarı elde edilmiştir (Okunaka ve ark., 1990; McCaughan ve ark., 1996).

FDT'nin en önemli avantajları lokal ilerlemiş özofajiyal kanserde disfajinin günler içinde iyileşmesi, minimal ağrı oluşması ve bilinçli sedasyonla işlemin gerçekleştirilebilmesidir. Radyoterapi veya kemoterapi gibi diğer tedavi metotlarıyla birlikte kullanılabilir. Başlıca dezavantajları ise sınırlı yaşam beklentisi olan hastalarda deri fotosensitivitesi ve özel aletlerinin pahalı olmasıdır. Ayrıca FDT tümör kanamalarının kontrol altına alınmasında ve özofajiyal stentlere bağlı tümör lümen içi ve dışına doğru büyümelerin tedavisinde de etkilidir (Litle ve ark., 2003).
Özofajiyal perforasyon riskini minimale indirgemek için FDT sonrası tümör nekrozu ve penetrasyonun derinliği 5 mm'ye sınırlandırılır. Litle ve ark. 215 hastalık çalışmalarında perforasyon oranını \% 1,5 olarak bildirdiler (Litle ve ark., 2003).

\section{Endoprotez yerleștirilmesi}

Özofajiyal endoprotezlerin kullanılmaya başlandı $\breve{g}_{1}$ yaklaşık 150 yıllık bir süreçte basit bir borudan kendiliğinden genişleyebilen plastik ve metal stentlere kadar gelişme olmuştur. İlk kez Domschke ve ark. tarafindan 1990 yılında gerçekleştirilen malign özofajiyal striktürün kaplı olmayan genişleyebilen metalik stent ile başarılı tedavisi sonrası özofajiyal stent tedavisinde hılı bir ilerleme gözlenmiştir (Domschke ve ark., 1990).

Son 20 yıldaki kaplı ve kaplı olmayan metalik ve plastik stentlerde yeni gelişmelerle birlikte malign özofajiyal darlıkların palyasyonunda stent tedavisi ilk sırayı almıştır. İlerleyen dönemlerde benign darlıklarda ve çeşitli komplikasyonlarda da stent kullanımı giderek artış göstermiştir.

Genişleyebilen metalik özofagus stentleri rijit plastik stentlere göre daha pahalı olmasına rağmen daha az sıklıkta komplikasyonlara yol açmaktadır. Bu nedenle daha ekonomik bulunmuşlardır. Prospektif randomize bir çalışmada laser ile rekanalizasyonla kıyaslandığında genişleyebilen stentlerin semptomları düzeltmede daha üstün olduğu ve tekrarlayan müdahale ihtiyacını azalttı̆̆ı görülmüştür (Giral ve Kalayc1, 2002).

Kendiliğinden açılabilen metalik stentlerin geliştirilmesi ile özofagus kanserinin palyasyonunda oldukça ilerlemeler kaydedilmiştir. Rijit tüplerden avantajları yerleştirme cihazının dar olması, önceden dilatasyon yapılmasına gerek olmaması ve hafif sedasyonla endoskopi veya floroskopi rehberliğinde yerleştirilebilmesidir (Tan ve ark., 1996). Kendiliğinden genişleyebilen metalik stentler \% 95 oranında başarı ile yerleştirilebilmekte olup işleme bağlı mortalite oranı \% 1,5'ten daha azdır (Eroğlu ve ark., 2009). Olguların büyük bir kısmında katı gıdaları alabilecek şekilde yutma güçlüğünde rahatlama sağlanmaktadır.

\section{Endikasyonlar}

Günümüzde özofajiyal stentlerin en sık kullanım ala$\mathrm{n} 1$ cerrahinin uygun olmadığ dır. Bunun yanında benign özofajiyal darlıklarda, özofagus perforasyonunda, benign-malign ÖRF'de ve cerrahi sonrası anastomoz kaçaklarının tedavisinde özofajiyal stent kullanımı giderek artı̧̧ göstermektedir (Eroğlu ve ark., 2009; Turkyilmaz ve ark., 2009).

İnoperabl özofagus kanserinde radyoterapi, kemoterapi, laser tedavi, intratümöral etanol enjeksiyonu, konvansiyonel plastik veya metalik stent gibi palyatif yaklaşımlar uygulanmıştır. Disfaji semptomlarında rahatlama ve hayatı tehdit edici komplikasyonlar diğer metodlarla karşıllaştırıldığında stent kullanımında yoğunlaşmaya yol açmıştır (Baron, 2001; Golder ve ark., 2001).

Özofagus kanserinin en ölümcül komplikasyonu ÖRF olup, özofagus kanseri olan hastalarda ÖRF gelişme riski yaklaşık \% 5-15'tir (Tomaselli ve ark., 2001; Shin ve ark., 2004; Murthy ve ark., 2007). Günümüzde endoskopik özofajiyal stent yerleştirilmesi malign ÖRF için en iyi tedavi seçeneği olarak görülmektedir (Turkyilmaz ve ark., 2009). 
Rekürren özofajiyal stenoz ile yüksek oranda uzun dönem komplikasyon oranları ve doku hiperplazisi benign lezyonlarda stent kullanımının istenmeyen etkileridir. Bununla birlikte birkaç ay sonra stentin çıkartılması ile başarılı sonuçlar bildirilmiştir (Song ve ark., 2000).

\section{Özofagus ve stent etkileşimi}

Metal stent stenoz içinde açıldığında, stenotik tümör ve komşuluğundaki normal mukozaya basınç uygulayarak nekroz oluşturur. Stent tümör ve normal mukozaya doğru açılmaya devam ederek mukoza içinde kronik inflamatuar yanıt oluşturur. Stent fibrotik ortam içinde gömülür. Bazen stent içi epitelize olur, bazen de düz yüzey oluşturan kollajenöz bir materyalle kaplanır. Zamanla stent müskülaris propriyaya hatta adeventisyaya ulaşabilir.

Proksimal ve distal kenarlarda sağlam yassı hücre ile kaplı mukozada sıklıkla benign hipertrofi meydana gelmektedir. Bu durum olguların yaklaşı \% 50'sinde görülebilmektedir (Giral ve ark., 2002). Özofagus stentinin tüm tiplerinde sekonder striktürler oluşabilmektedir. Proksimal çapı geniş olan stentlerde granülasyon dokusu ile birlikte gelişen reaktif hiperplazi veya fibrozis daha sık görülmektedir. Sonuç olarak stent yerleştirilmesi sonrası görülen sekonder striktürlerin açılması için yeniden müdahale gerekmektedir.

Membran kaplı stentlerde, kaplı kısımlarda mukozal gömülme olmayıp mevcut mukoza yapısında belirgin değişiklik görülmez. Ancak buna bağlı olarak stent migrasyonu daha sık görülür. Tamamen membran ile kaplı stentlerde migrasyon oranı yaklaşık \% 30'dur. Membranla kaplı olmayan stent kısımlarının ise özofagusla bütünleşmesi 8-12 hafta içinde tamamlanır (Giral ve ark., 2002). Membranla kaplı olmayan stentlerde düşük migrasyon oranları olmasına rağmen lümen içine tümör büyümesi sık görülmektedir.

\section{Stent tipleri}

Metalik stentler kaplı veya kapsız olabilir. Çelik veya nitinol içerebilir. Açıldıklarında çapları 2,5 cm'dir. En sık tipleri nitinol ultraflex stent, Wallstent ve Gianturco Z stent'tir (Watkinson ve ark., 1995). Erken dönem sonuçları iyi olmasına rağmen uzun dönemde vakaların yaklaşık \% $\quad 40$ 'ında problemler izlenebilmektedir.

\section{Wallstent}

Paslanmaz çelikten yapılmıştır. Floroskopi eşliğinde ilerletilen fleksibl bir kateter kullanılarak açılır. Açılma işlemini görüntülemek için stentin yanında endoskop ilerletilebilir. Yeni modeli tekrar yerleştirmeye imkan tanıyacak şekilde \% 50 açılıncaya kadar zorlanabilir. Wallstentler günümüzde daima poliüretan kaplıdır. Açıldıktan sonra çıkartılacak şekilde tasarlanmıştır. Wallstentlerde açılma 24-48 saat devam eder (Eroğlu ve ark., 2009). Nadiren açılmakta olan stentlerde balon ile dilatasyon gerekebilir. Stent birakıldıktan sonra endoskopla kontrol edilmesi stentin yerinin değişmesine neden olabilir. Bu nedenle floroskop kontrol edilmesi daha uygundur. Oral beslenmeye stent yeteri kadar açıldıktan sonra başlanmalıdır. Ticari olarak üç ürün mevcuttur.

I. Poliüretan kaplı tübüler özofajiyal Wallstent: 20 mm kenar çapta ve $110 \mathrm{~mm}$ toplam uzunlukta, $25 \mathrm{~mm}$ kenar çapta ve $105 \mathrm{~mm}$ toplam uzunluktadırlar. Taşıyıcıları sırasıyla $18 \mathrm{~F}$ ve $22 \mathrm{~F}$ çaptadır.

II. Kaplanmamış tübüler özofajiyal Wallstent: 20 veya
$22 \mathrm{~mm}$ kenar çaplı, 70 veya $100 \mathrm{~mm}$ toplam uzunluktadırlar. Stentler $11 \mathrm{~F}$ taşıyıcıya yüklenmişlerdir.

III. Flamingo özofajiyal Wallstent: Distal özofagus ve kardiya yerleşimli tümörler için geliştirilmiştir. Bu nedenle proksimal yarısında radyal kuvvet fazla iken distal yarısında radyal kuvvet az, ancak hareketlilik daha fazladır. Proksimal çap1 $30 \mathrm{~mm}$, distal çap1 $20 \mathrm{~mm}$, uzunluğu ise $14 \mathrm{~cm}$ olan ve proksimal çap1 $24 \mathrm{~mm}$, distal çap1 $16 \mathrm{~mm}$ ve uzunluğu 12 cm olmak üzere iki ayrı ölçüde flamingo özofajiyal wallstent tasarlanmıştır (Giral ve ark., 2002).

\section{Z Stent}

$\mathrm{Bu}$ stentler $2 \mathrm{~cm}$ uzunluğunda birbirleriyle $\mathrm{Z}$ şeklinde birleşen çelik tel sıralarından oluşmuş silindirik yapıdadır. Silindirler arzu edilen uzunluğu sağlamak üzere birleştirilir. Polietilen filmle kaplanması nedeniyle tümörün içe doğru büyümesi belirgin şekilde azalır ve ayrıca gerekirse çıkarılması kolaylaşır. Uçtaki silindirler parlaktır ve merkezde olası migrasyonu engelleyecek küçük kancaları vardır. Kateteri oldukça rijit yapıda olup rehber kablo üzerine oturtulmadan önce nispeten komplike bir yükleme işlemi gerektirir. Ticari olarak geliştirilen Wilson-Cook Z stentleri 21 ve $25 \mathrm{~mm}$ kenar, 18 mm gövde çaplı ve 8, 10, 12 ve $14 \mathrm{~cm}$ uzunluktadır. Cook Z stentleri ise $25 \mathrm{~mm}$ kenar ve $16 \mathrm{~mm}$ medyal çaplı ve 10,12 ve $14 \mathrm{~cm}$ uzunluktadır. Cook-Z stentlerinde migrasyonu azaltıcı sabitleyicileri olanlar da vardır (Rahmani ve ark., 1999; Giral ve ark., 2002).

Gastrik içeriğin reflüsünü önlemek amacı ile gastroözofajiyal bileşkeyi kateden lezyonların palyasyonunda kullanılmak üzere Dua anti-reflü kapaklı bir Z stent geliştirilmiştir. Bu stent kaplı bir Z stenttir ve distal ucunda 7 cm'lik kompresibl kapağı vardır. Bu stentle olan deneyimler kısıtlıdır. Benzer stente sahip 30 hastanın değerlendirildiği bir çalışmada gastroözofajiyal reflünün engellenmesinde başarısız bulunmakla birlikte Amerika Birleşik Devletleri'nde bulunmayan bir stent (Fe X-Ella) bu konuda yararlı bulunmuştur (Homs ve ark., 2004; Shim ve ark., 2005).

\section{Ultraflex stent}

Tek tabaka halindeki örgü şekilli nitinolden (nikeltitanyum alaşımı) yapılmıştır. İnce bir tıkaç maddesi ile kaplıdır. Sıkıştırılmış durumdan açık duruma getirilmesi stenti sağlamlaştıran bir sütürün kademeli olarak çıkarılması ile olmaktadır. Nitinolden dolayı stentler süperelastik özellik göstermektedirler.

$\mathrm{Bu}$ stentler Wallstentlerden daha az ışınsal kuvvet sergilemektedirler. Wallstentle karşılaştırıldığında çıplak metal uçları yoktur. Böylece mukozayı daha az travmatize ederler. $\mathrm{Bu}$ durum stentin aort ve solunum yollarında erozyon oluşturma riskini azaltabilir. Teorik olarak çıkartılabilirler. Fleksibl olmaları nedeniyle ultraflex stentler, proksimal lezyonların stentlenmesinde iyi bir seçenek olarak kabul edilmektedirler. Proksimal çapın 23 ve $28 \mathrm{~mm}$ olmak üzere iki ölçüsü vardır. Gövde çapı kaplı olanda $17 \mathrm{~mm}$, kaplanmamış olanda ise 18 mm'dir. Proksimal çapı $23 \mathrm{~mm}$ olanın 7, 10, 12 ve $15 \mathrm{~cm}$ boyda olanları bulunmaktadır. Çapı $28 \mathrm{~mm}$ olanın ise 7, 10 ve $12 \mathrm{~cm}$ boyda olanları vardır. Kaplanmış stentlerde poliüretan kaplama kenarlara $15 \mathrm{~mm}$ kalana kadar devam etmektedir. Stentin tam açılması 2-4 gün sürer. Ultrafleks özofajiyal stentin uygulanabilmesi için striktürün en az 12 mm'lik dilatasyo- 
nu gereklidir (Giral ve ark., 2002).

Ultraflex stentlerin kaplı ve kaplı olmayan formları bulunmaktadır. Fakat kaplı olmayan stentler içe doğru doku büyümesine meyillidir. Elli dokuz hasta ile yapılan bir çalışmada balon dilatasyonu ve ek stent yerleştirilmesinden sonra bile \% 36 düzeyinde içe doğru ve taşma şeklinde büyüme izlenmiş olup, olguların yarısında tekrar girişim gerekmiştir (Acunas ve ark., 1996).

\section{Esophacoil stent}

Nikel-Titantum alaşımı yassı telden ibaret bir yay şeklindedir. Serbest bırakıldığında her iki uçtan \% 25 oranında kısalma görülür. Mukozal fiksasyonu artırmak amacıyla proksimal ve distal çapı daha geniş olmak üzere, kaplı gövde çap1 14, 16, 18 ve $20 \mathrm{~mm}$ boyu 10 ve $15 \mathrm{~cm}$ olan ölçüleri bulunmaktadır (Wengrower ve ark., 1988; Giral ve ark., 2002). Yukarıda bahsedilen stentlerin hepsi bir metal alaşımdan üretilmiştir. Polyflex (Microvasive, Boston Scientific, Inc, Natiek, MA) olarak adlandırılan kendiliğinden genişleyebilen plastik stent de geliştirilmiştir (Decker ve ark., 2001; Dormann ve ark., 2003). Polyflex stent, çevre dokularda daha az travmaya yol açmaktadır. Metalik stentlere göre doku hiperplazisi ve/veya fistül gelişimi azalabilmektedir. Polyflex stent tekrar çıkartılabilir nitelikte olup benign oluşumlar için uygun bulunmaktadır. Bu stentle olan deneyimler gittikçe artmaktadir.

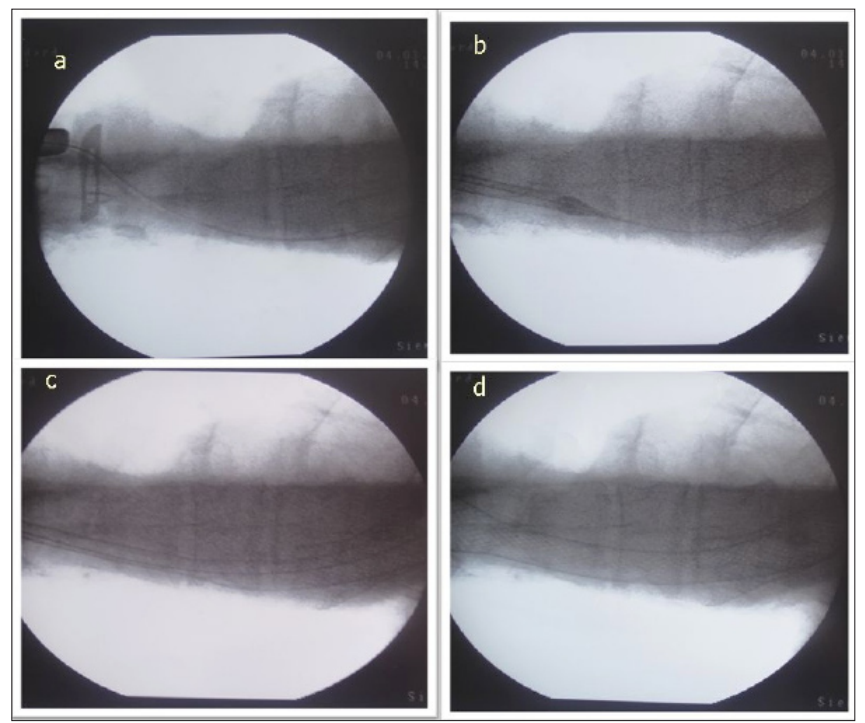

Şek. 1. Stent takılma aşamaları

\section{Stent yerleştirme tekniği}

Stent yerleştirilmeden önce kontrastlı özofagogram ile striktürün lokalizasyonu, uzunluğu ve trakeoözofajiyal fistül (TÖF) bulunup bulunmadığı gösterilmelidir. Sedatif ve analjeziklerle (intravenöz 3-5 mg midazolam ve $50 \mathrm{mg}$ meperidin) hastanın rahatlatılması sağlanabilir. Özofajiyal kendiliğinden genişleyebilen metalik stent (KGMS) floroskopi kullanarak veya kullanmayarak endoskopi rehberliğinde yerleştirilebilir (Şek. 1).

Üreticiler stentin açılmasına izin vermek amacıyla 6-10 mm'lik minimal lümen çapını sağlamak üzere işlemden önce darlığın dilate edilmesini önermektedir. Darlığın uzunluğu doğru ölçülerek stent neoplazm veya striktürden 3-4 cm uzun olacak şekilde planlanmalıdır. Proksimal özofajiyal lezyonlar için genişleyebilen stent yerleştirilmesi teknik olarak güç ola- bilmesine rağmen bu stentler servikal özofagus obstrüksiyonlu hastalarda başarılı bir şekilde yerleştirilmektedir (Bethge ve ark., 1997). Bu kesici dişlerden itibaren ölçülen uzunlukların gösterilmesi, kaydedilmesi ve endoskopi görüntüleri eşliğinde stentin yerleştirilmesi ile başarılabilir. Daha sık olarak tümörün kenarlarına yerleştirilmiş eksternal markerları belirlemek için eş zamanlı floroskopi kullanılabilmektedir. Endoskopik hemostaz için kullanılan metal klipler, stent açılmadan önce tümörün proksimal ve distal sınırını belirlemek amacı ile kullanılmaktadır. Daha sonra endoskopi rehberliğinde stent yerleştirme işlemine geçilir. Stent yerleştirilmesinde başarı oranları sadece elde edilen disfaji skoru ile değil, aynı zamanda uzun süreli takipte izlenen komplikasyonlar ile de değerlendirilmelidir.

\section{Komplikasyonlar}

Stent uygulaması kolay olup hızlı bir şekilde disfaji düzelmektedir. Bununla beraber stent yerleştirilmesine bağlı erken ve geç dönemde bazen hayatı tehdit edici komplikasyonlar ortaya çıkabilmektedir.

KGMS olan Ultraflex stentler oldukça fleksibldır ve malign özofajiyal darlıklarda güvenle kullanılmaktadır. Schmassmann ve ark. (1997) Ultraflex stentlerle karşılaşt1rıldığında Wallstent kullanımında işlemle ilgili mortalite ve şiddetli persistan ağrının daha fazla görüldüğünü bildirdi (Schmassmann ve ark., 1997). Siersema ve ark. (2001) kapli Ultraflex stent ve Flamingo Wallstent kullanımında major komplikasyonları Gianturco-Z stent kullanımından daha az sıklıkta bildirmişlerdir (Siersema ve ark., 2001). Bununla beraber Ultraflex stent kullanımında uzun dönem takiplerde major komplikasyonlar bildirildi. Diğer yandan Dorta ve ark. (1997) Wallstent ile karşılaştırıldığında yetersiz ekspansiyon kapasitesi nedeniyle Ultraflex stentte inkomplet dilatasyonun daha fazla olduğunu bildirmişlerdir (Dorta ve ark., 1997).

\begin{tabular}{l} 
Tablo 2. Stent komplikasyonları \\
\hline Major komplikasyonlar \\
\hline Kanama \\
Aspirasyon pnömonisi \\
Trakeal bası \\
Perforasyon \\
Özofagorespiratuar fistül \\
Minör komplikasyonlar \\
\hline Göğüs ağrısı \\
Tümörün aşrı̈ıüymesi \\
Tümörün içe doğru büyümesi \\
Gastroözofajiyal reflü \\
Hıçkırık \\
Yabancı cisim hissi \\
Stent açılmasında yetersizlik \\
Migrasyon \\
Granülasyon dokusu oluşumu \\
Bolus gıda obstruksiyonu \\
Stent kırılması \\
Stent yerleştirilememesi \\
\hline
\end{tabular}

Prosedürle ilişkili komplikasyonlar rijit plastik endoprotezlerle karşılaştırıldığında metalik stentlerle tedavi edilen hastalarda daha düşük oranda tespit edilmiştir (Sabharwal ve ark., 2005). Önceden radyoterapi, kemoterapi veya her ikisini alan hastalarda genişleyebilen metalik stent yerleştirildiğinde geç dönem özofajiyal komplikasyon riskinin arttığı belirtilmiştir (Siersema ve ark., 1998). 


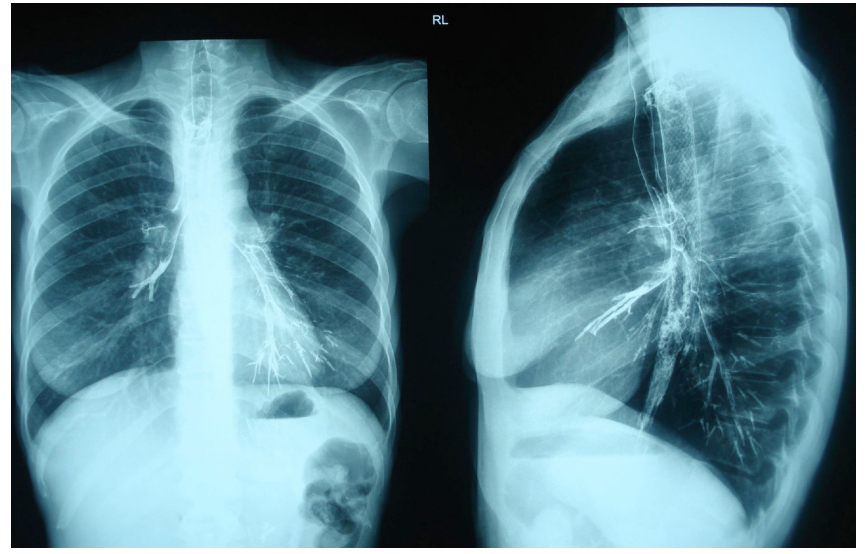

Şek. 2. Özofagus orta kesime konulmuş bir stentin trakeayı rüptüre ettiği görülüyor

Kawasaki ve ark. (2003) fistül oluşumu, masif fatal hemoptizi, hematemez ve trakeal kompresyon nedeniyle dispne veya stridordan oluşan major komplikasyon oranını \% 30 olarak bildirmişlerdir (Kawasaki ve ark., 2003). Siersema ve ark. (1998) özofagogastrik kanser nedeniyle stent yerleştirdikleri hastaların \% 23 'ünde major komplikasyon ve \% 33'ünde minör komplikasyon ortaya çıktığını bildirmişlerdir. (Siersema ve ark., 1998). Özofajiyal stente bağlı major komplikasyonlar üst özofajiyal kısımda diğer özofajiyal kısımlara göre daha fazla ve daha erken dönemde tespit edilmiștir (Kawasaki ve ark., 2003). Özofajiyal stentlere bağlı görülen komplikasyonlar Tablo 2'de gösterilmiştir.

\section{a. Major komplikasyonlar}

Perforasyon, özofagus kanserli hastalarda stent yerleştirilmesine bağlı en çok korkulan komplikasyonlardan biridir (Şek. 2). Perforasyonun mortalite oranı oldukça yüksektir. Plastik stentlerde perforasyon riski \% 10'dan fazla, kendiliğinden genişleyebilen metalik stentlerde ise \% 5'den daha az bulunmuştur (Wang ve ark., 2001).

Stent özofajiyal sfinkterlerden birinde ise özofajit ve aspirasyon pnömonisi görülme olasılığı yüksektir. Özofajiyal karsinomalı hastaların bir kısmında önceden var olan kronik gastroözofajiyal reflü mevcuttur. Bu vakalarda stent yerleştirilmesi sonrasında disfajinin rahatlamasıyla rekürren gastroözofajiyal reflü olacaktır. Trakeal kompresyon özofajiyal stent yerleştirilmesine sekonder nadir görülen, fakat ciddi bir komplikasyondur. Bilgisayarlı tomografi veya bronkoskopide trakeal kompresyon gösterilmişse veya balon dilatasyonu respiratuar distrese neden oluyorsa özofajiyal stent yerleştirilmemesi önerilmektedir (Therasse ve ark., 2003). Postmortem incelemelerde stent yerleştirilmesi sonrasında stent kenarının aorta ve özofajiyal duvarda nekroza yol açarak fatal hemorajiye yol açtığı gösterilmiştir. Aynı zamanda aortal duvara invaze özofajiyal tümörde stent yerleştirilmesi rüptür ve hemorajiye yol açabilir (Siersema ve ark., 1998).

\section{b. Minör komplikasyonlar}

Özofajiyal stent yerleştirilmesini takiben hastalarda en sık şikayet çeşitli derecelerde olan gögüs ağrısıdır. Bu ağrının en olası nedeni stentin ekspansiyonu ile tümöral dokuyla istila edilmiş özofagus lümeninin dilate olması ve gerilmesidir. Erken dönemde göğüs ağrısı hastaların hemen hemen tümünde olmakta iken uzamış göğüs ağrısı hastaların \% 13'ünden daha azdır (Acunas ve ark., 1996).

Kaplı stentler özellikle kardiaya yerleştirildiğinde olgu-

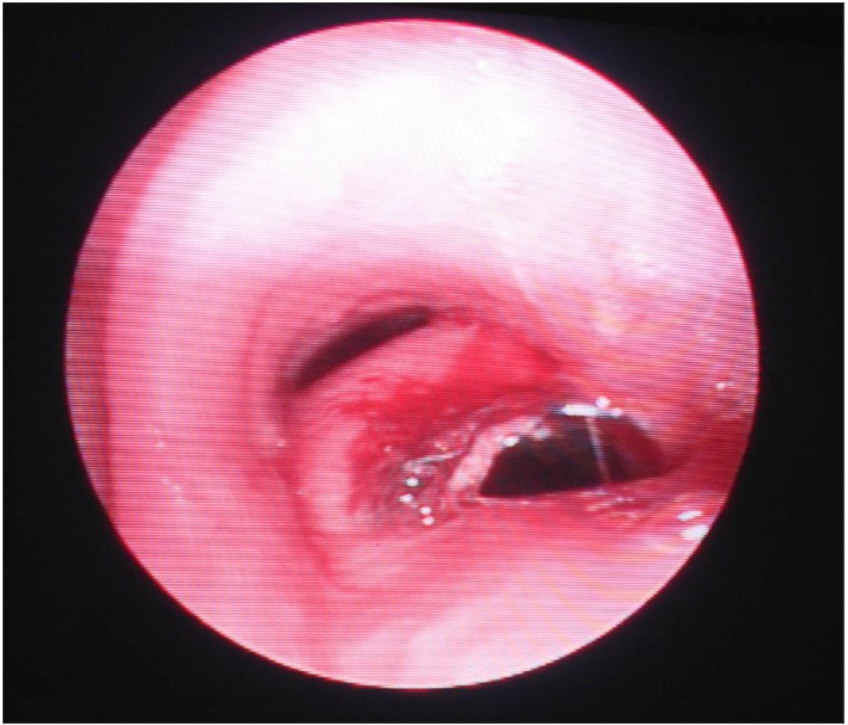

Şek. 3. Şek. 2'deki olgunun bronkoskopik görünümü

ların yaklaşık 1/3'ünde migrasyon görülmektedir (Wang ve ark., 2001). Flamingo stent gibi sonradan tasarlanan yeni stentlerle migrasyon oranı oldukça azaltılmıştır (Sabharwal ve ark., 2003).

Özofajiyal stent sonrası tekrarlayan disfajinin en yaygın sebebi tümör dokusunun lümen içine veya dışına doğru büyümesidir. Kaplı stent yerleştirilmesi tümörün lümen içine doğru büyümesini önleyebilir. Fakat tümörün lümen dişına doğru büyümesini ve stent kenarındaki benign hiperplastik doku gelişimini önleyemez. Bununla birlikte yeni bir stent yerleştirilmesiyle bu problemler çözülebilir (Şek. 3).

Malign özofajiyal striktür için yerleştirilen metalik stentler bazen benign striktür gelişmesine neden olabilir. Mayoral ve ark. (2000) stent yerleştirilmesi sonrası tekrarlayan disfaji gelişen hastaların \% 47'sinde nonmalign striktür oluştuğunu bildirmişlerdir. Servikal özofagus tümörlerinde lezyondan daha proksimale stent yerleştirilmesinde hastalarda yabancı cisim hissi oluşabilmektedir. Bazen stent ekspansiyonunda yetersizlik görülebilmektedir. Nadiren özofagus lümeni tamamen tümör ile tıkalı olup stent yerleştirilemeyebilir.

Özofajiyal stent yerleştirilmesi basit, hızlı ve etkili bir yöntem olmasına rağmen komplikasyon oranı yüksektir. Hastaların yaklaşık 1/3'ünde endoskopik re-intervasyon gerekmektedir. Bununla birlikte endoskopik re-intervasyon ile vakaların çoğunda bu komplikasyonlar başarılı bir şekilde tedavi edilebilmektedir (Turkyilmaz ve ark., 2010).

\section{Cerrahi tedavi}

Lokalize ve erken evre özofagus kanserinde küratif amaçla cerrahi tedavi uygulanmaktadır. Ancak palyasyon amacıyla özofajektomi kabul edilemeyecek yüksek mortalite oranları nedeniyle önerilmemektedir. Endoskopik tekniklerdeki ilerlemelerle birlikte özofagus kanserinin palyasyonunda cerrahinin kullanımı oldukça sınırlandırılmıştır. Postoperatif ağrı, iyileşme süresi ve sağ kalım beklentisi cerrahi palyasyonu kısıtlamaktadır. Ayrıca cerrahi seçenekler endoskopik tekniklerden daha fazla ciddi komplikasyon ve mortalite riski taşımaktadır. Bu nedenle cerrahi palyasyon genel durumu çok iyi, yaşam beklentisi 1 yıldan uzun olan ve diğer palyatif metotların kontrendike veya yetersiz olduğu durumlarda uygulanabilir( Korst ve Ginsberg 2005).

I. Rezeksiyon: Lokal hastalık veya bölgesel lenf nodun- 
da sınırlı tutulumu olan tüm hastalar küratif tedavi açısından değerlendirilmelidir. Ne yazık ki operasyona alınan birçok olguda sadece inkomplet palyatif rezeksiyon yapılabilmektedir. Uzak bölge lenf nodu tutulumu veya metastatik hastalığ lunan olgularda küratif rezeksiyondan söz edilemez. Cerrahi rezeksiyon sadece olağan dışı durumlarda tümörün tamamen çıkartılması mümkün ise palyatif bir manevra olarak uygulanabilir.

Yutma fonksiyonlarında hızlı bir düzelme sağlayan postoperatif komplikasyonsuz bir cerrahi başarılıdır. Ancak palyatif rezeksiyonlar yüksek miktarda postoperatif komplikasyon ve mortaliteyle birliktedir. Palyatif rezeksiyonlarda ortalama sağ kalım 6 aydan daha az, kombine morbidite ve mortalite \% 30'dan fazladır (Korst ve Ginsberg, 2005).

$\mathrm{Bu}$ hastalarda özellikle tümör karinanın üzerinde ise eş zamanlı kemoterapili veya kemoterapisiz radyoterapinin cerrahi rezeksiyon kadar palyasyon sağladığı belirtilmektedir (Stoller ve ark., 1984). Karinanın altındaki dairesel obstruksiyon yapan tümörler kür için yetersiz ve inkomplet rezeksiyon olmasına rağmen palyatif olarak en iyi şekilde tedavi edilirler. Bu bölgede radyasyon tarafindan oluşturulan striktür önemli derecede disfaji ve hayat kalitesinde kötüleşme ile sonuçlanır.

Adenokarsinomalarda radyoterapiye hızlı cevap nadirdir. $\mathrm{Bu}$ tedavi formu hastanın kalan ömründe palyasyon sağlamayabilir. Bununla birlikte inkomplet bir rezeksiyonda erken tekrarlayan disfajili hastaların yaklaşık \% 40'ında lokal hastalığın rekürrensi görülmektedir (Giuli ve ark., 1980). Bu nedenle komplet rezeksiyon yapılamayacak tümörlerde bu durum akılda tutulmalıdır.

II. Bypass: Yirminci yüzyılın başlarından itibaren sindirim sisteminin devamlılığının sağlanması için anrezektabl özofagus kanseri için bypass operasyonu savunulmaya başlanmıştır (Kirschner, 1920). Yirminci yüz yılın son dekatında intralüminal protezlerdeki ilerlemeler ve olumlu sonuçları nedeniyle bypass cerrahisinden uzaklaşılmaya başlanmıştır. Protezlerin kullanılmasından önce anrezektabl tümörlerde bypass için en yaygın endikasyonlar ÖRF ve totale yakın obstruksiyondu. İntralüminal protezlerin geçişi sağlama ve ÖRF'yi kapatmadaki başarısı ile birlikte özofajiyal bypass kullanımı oldukça sınırlandırılmıştır

Bypass için en kolay metot presternal veya tercihan retrosternal yolu kullanarak laparatomi ve servikal insizyonla boyunda anastomozun oluşturulmasıdır. Sağ veya sol intratorasik yaklaşım kullanılabilir. Ancak anastomoz toraksta obstruksiyonun üzerinde veya boyunda yapılır.

Günümüzde özofajiyal bypass için endikasyonlar; laser veya stentle tedavi edilemeyen yüksek derecede özofajiyal obstruksiyon, anrezektabl özofajiyal tümörün kendiliğinden perfore olması ve stent uygulanamayan ÖRF ile sinırland1rılmıştır. Bu operasyonda ortalama sağ kalım 3-6 aydır (Burt ve ark., 1991; Horvath ve ark., 1996; Meunier ve ark., 1996). Günümüzde bu operasyonun mortalitesi \% 15-30 olup ÖRF varsa bu oran \% 33-55 arasındadır (Conlan ve ark., 1984; Hirai ve ark., 1989; Muller ve ark., 1990; Meunier ve ark., 1996; Cantero ve ark., 1999). Palyatif radyoterapi sonrası yapılacak palyatif bypass cerrahisinde sonuçlar daha iyi değildir (Iwasa ve ark., 1998).

III. Gastrostomi ve özofagostomi: Özofagus kanserinde gastrostominin palyatif tedavideki yeri belirsizdir. Gastrostomi ancak seçilmiş çok az vakalarda uygulanabilir. Benzer şe- kilde beslenme tüpü ile yapılan servikal özofagostomi hiçbir işlemin yapılamadığı vakalarda düşünülebilir.

\section{Kemoterapi}

Rekürren veya metastatik tümörü olan hastalarda tek ajanlı veya çok ajanlı olarak palyatif kemoterapi uzun zamandan beri kullanılmaktadır.

\section{Tek ajanlı uygulamalar}

Özofagus kanserinin palyasyonunda tek başına etkili olduğu bildirilen ilaçların başında cisplatin gelmektedir. Cisplatin ile \% 20-30 civarında fayda alındığ tedir. Tek ajan olarak etkili olduğu gösterilen diğer bir ilaç 5-flourourasil'dir (5-FU). 5-FU ile \% 20-50 arasında değişen oranda yanıt alındığ misin ile de yaklaşı \% 20 başarı oranı bildirilmişstir (Ökten, 2003).

\section{Kombine kemoterapi uygulamaları}

Faz II çalışmalarda cisplatin bazlı kombinasyonlarda özofagus kanserli hastaların çoğunda disfajide rahatlama olduğu görülmüştür (Ilson ve ark., 2000). Faz II bir çalışmada metastatik özofagus kanserli hastalarda cisplatin ve irinotecan sonuçlarını bildirdi. Daha önce tedavi edilmemiş metastatik adenokarsinom veya yassı hücreli kanseri olan hastalara cisplatin $\left(30 \mathrm{mg} / \mathrm{m}^{2}\right)$ ve irinotecan $\left(65 \mathrm{mg} / \mathrm{m}^{2}\right) 1,8,15$ ve 22 . günlerde verilip iki hafta ara verildi. Cisplatin/irinotecan kombinasyonu ile 20 hastanın 14'ünde disfajide tam bir düzelme görüldü. Ayrıca 4 hastada kısmi bir rahatlama gözlendi. Bu faydalar tedaviden ortalama 1-6 hafta sonra gözlendi. Özofagus kanserli hastalarda bu ve diğer faz II çalışmalarda sistemik kemoterapinin disfaji palyasyonunda başarılı olabileceğini göstermektedir (Spiridonidis ve ark., 1998; Ilson ve ark., 1999; Ilson ve ark., 2000; Tebbutt ve ark., 2002). Bununla birlikte sistemik kemoterapinin uygulanmasına bağlı toksisiteye karşı dikkatli olunmalıdır. Günümüzde en sık kullanılan rejim cisplatin $100 \mathrm{mg} / \mathrm{m}^{2} 1$. gün ve $5-\mathrm{FU}$ x4-5 gündür. İleri evre hastalarda \% 35 oranında yanıt alındığı bildirilmektedir (Turhal, 2002).

Palyasyon için tümör bölgesine lokal kemoterapi verilmesi günümüzde araştırılmaktadır. Bu uygulama ile sistemik toksisite minimale indirgenebilir. Lokal ilaç uygulamasında tümör içinde ilaç konsantrasyonunun artırılması önemli bir avantajdır (Javle ve ark., 2006). Obstruksiyon yapan kanser dokusuna kemoterapi ajanı verilmesi alkol enjeksiyonu veya bipolar elektrokoagülasyon kullanılarak yapılan elektrokimyasal koterizasyona bir alternatiftir. Bununla birlikte s1k rekürrensler nedeniyle tedavinin tekrar uygulanması gerekir. Bu metotla ilgili göğüs ağrısı, mediastinit, TÖF ve perforasyonu içeren potansiyel komplikasyonlara ait tecrübe azdır.

\section{Radyoterapi}

Kemoterapi ile eş zamanlı 50.4 Gy dozunda radyasyon uygulandığında lokalize hastalıkta tam bir tedavi elde edilebilir. Daha yüksek dozlarda verildiğinde ise terapotik değeri artmaz ancak lokorejiyonel toksisitede artış görülür (Minsky ve ark., 2002; Javle ve ark., 2006). İlerlemiş veya metastatik hastalıkta palyasyon amaciyla 30-37,5 Gy dozunda kullanılır. Karinanın üzerindeki lezyonlarda radyoterapi öncesi tanısal bronkoskopi önerilmektedir. Özofagusun 1/3 proksimalini tutan tümörlerde TÖF riski varsa ve hastada TÖF'ten şüpheleniliyorsa radyoterapi ile tedavi uygulanmamalıdır.

Özofagus kanserinde esas problem tümörün büyümesidir. 
Eksternal radyoterapi tümörün büyümesi üzerine etkili olup diğer metotlara göre daha uzun palyasyon sağlamaktadır. Disfajinin palyasyonu için radyoterapi verilen hastalarda radyoterapi sonrası hem malign hem de benign striktür görülebilir. O'Rourke ve ark. (1988) radyoterapi sonrası malign ve benign striktür sıklığını eşit oranda bildirdiler. Benign striktürlü hastaların çoğu dilatasyon ile tedavi edilip 1 yıllık sağ kalım \% 88 iken bu oran malign striktürlerde \% 19 olarak bildirildi.

Özofajiyal kanserde disfajinin palyasyonunda intralüminal radyoterapi (brakiterapi) diğer bir alternatiftir (Sur ve ark., 1988). Bununla birlikte brakiterapi sınırlı kullanılabilirliği ve tedavi sonrası sık rekürrens görülmesi nedeniyle nadiren kullanılmaktadır. Diğer bir dezavantajı ise tedavi sonrası bir hafta kadar doku ödemine yol açarak disfajiyi geçici olarak arttırmasıdır. Bu nedenle ciddi disfajiyle gelen hastalarda brakiterapi ilk metot olarak uygulanmamalıdır.

\section{Özofagus kanserinde palyasyon metotlarının karşı- laştırılması}

Fotodinamik tedavi (FDT) ve stent: Cerrahi tedavi planlanamayan disfaji yakınması olan bütün hastalarda hem stent hem de FDT göz önünde bulundurulmalıdır. FDT özofagus kanseri ile ilişkili kanamaları durdurmada mükemmel bir seçimdir (Litle ve ark., 2003). Tümörün mukozayı tuttuğu durumlarda FDT en çok etki etmektedir. FDT primer olarak endolüminal içeriği olan tümörlerde kullanılmalıdır. Stentler ise ekstra veya endolüminal büyük tümörlerde daha etkilidir.

Tümör lokalizasyonu tedavi metodunun seçiminde önemlidir. Servikal bölge tümörlerinde FDT stente tercih edilmelidir. Distal özofagus kanserleri FDT ile daha iyi tedavi edilirler. Gastroözofajiyal bileşkeye yakın yerleştirilen stentlerde önemli derecede reflü görülebilmektedir. Bazı merkezlerde distal tümörlerde reflüyü minimale indirmek için kapaklı stentler önerilmektedir. Laasch ve ark. (2002) standart kendiliğinden genişleyebilen metalik stentlerle kapaklı stentleri karşılaştırdıklarında reflü oranlarında önemli derecede fark olduğunu bildirmişlerdir (\% 96'ya karşı \% 12) (Laasch ve ark., 2002).
Laser ve stent: Stentler laserlere göre disfajide daha iyi bir düzelme sağlar. Adam ve ark. (1997) randomize bir çalışmada 60 hastaya laser tedavisi, kapsız ve kaplı stent uygulamışlar ve malign disfajinin palyasyonunda stent yerleştirilmesinin daha etkin olduğu sonucuna varmışlardır (Adam ve ark., 1997). Başka bir randomize kontrollü çalışmada da kendiliğinden genişleyebilen metalik stentlerin lasere göre semptomlarda daha iyi bir düzelme sağladığı ve tekrar girişim oranının daha düşük olduğu bildirilmiştir (Verschuur ve ark., 2007).

Brakiterapi ve stent: Randomize bir çalışmada brakiterapi ve stent sonuçları karşılaştırılmıştır (Homs ve ark., 2004). Disfajideki düzelmenin stentten sonra daha kisa sürede geliştiği gözlenmiştir. Ancak brakiterapi ile daha uzun süreli bir düzelme elde edilmiştir. Bu çalışmada brakiterapi sonrası komplikasyon oranının daha düşük olduğu bildirilmiştir (\% 33'e karşı1ık \% 21). Tedavi grupları arasında persistan veya rekürren disfaji açısından fark saptanmamıştır.

Laser ve brakiterapi: Bu iki metodu karşılaştıran bir çalışma yoktur. Ancak ikisinin birlikte kullanıldığı çalışmalarda tek başına lazer tedavisinden daha uzun bir disfajisiz dönem sağladığı bildirilmiştir (Sander ve ark., 1991; Spencer ve ark., 2002).

Laser ve plastik tüpler: Disfajideki düzelme ve morbidite açısından fark saptanmamıştır (Alderson ve ark., 1990).

Laser ve etanol enjeksiyonu: Disfajideki düzelme ve tedavi sıklığı açısından fark saptanmamıştır (Currazoni ve ark., 1999).

Laser ve FDT: FDT teknik olarak laserden daha kolaydır ve hasta tarafindan daha iyi tolere edilebilir. Disfajideki düzelmedeki etkinlikleri eşittir. FDT proksimal ve distal yerleşimli darlıklarda daha etkili olabilir (Lightdale ve ark., 1995).

Stentler ve plastik tüpler: Metalik stentler daha avantajl1 bulunmuştur (Knyrim ve ark., 1993).

Sonuç olarak özofagus kanserli hastalarda malign disfajinin palyasyonunda tedavi seçimi hastalığın evresi, tümör lokalizasyonu, hastanın genel durumu ve hekimin tecrübesine göre değişecektir.

\section{KAYNAKLAR}

Acunas, B., Rozanes, I., Akpinar, S., Tunaci, A., Tunaci, M., Acunaş, G., 1996. Palliation of malignant esophageal strictures with self-expanding nitinol stents: Drawbacks and complications. Radiology. 199, 648-652.

Adam, A., Ellul, J., Watkinson, A.F., Tan, B.S., Morgan, R.A., Saunders, M.P., Mason, R.C., 1997. Palliation of inoperable oesophageal carcinoma: A prospective randomised trial of Laser therapy and stent placement. Radiology. 202, 344-348.

Alderson, D., Wright, P.D., 1990. Lazer recannalisation verses endoscopic intubation in the palliation of malignant dysphagia. Br. J. Surg. 77, 11511153.

Baron, T.H., 2001. Expandable metal stents for the treatment of cancerous obstruction of the gastrointestinal tract. N. Engl. J. Med. 344 , 1681-1687.

Bethge, N., Sommer, A., Vakil, N., 1997. A prospective trial of self-expanding metal stents in the palliation of malignant esophageal strictures near the upper esophageal sphincter. Gastrointest. Endosc. 45, 300-303.

Bisgaard, T., Wojdemann, M., Heindorff, H., Svendsen, L.B., 1997. Nonsurgical treatment of esophageal perforations after endoscopic palliation in advanced esophageal cancer. Endosc. 29, 155-159.

Boyce, H.W. Jr., 1984. Palliation of advanced esophageal cancer. Semin. Oncol. 11, 186-195.

Burt, M., Diehl, W., Martini, N., Bains, M.S., Ginsberg, R.J., McCormack, P.M., Rusch, V.W., 1991. Malignant esophagorespiratory fistula: Management options and survival. Ann. Thorac. Surg. 52, 1222-1229.

Cantero, R., Torres, A.J., Hernando, F., Gallego, J., Lezana, A., Suarez, A., Balibrea, J.L., 1999. Palliative treatment of esophageal cancer: Self-expanding metal stents versus Postlethwait technique. Hepatogastroenterology. 46, 971-976.

Cassidy, D.E., Nord, H.J., Boyce, H.W., 1981. Management of malignant esophageal strictures: Role of esophageal dilation and peroral prosthesis. Gastroenterology. 75, 173 .

Conlan, A.A., Nicolaou, N., Delikaris, P.G., Pool, R., 1984. Pessimism concerning palliative bypass procedures for established malignant esophagorespiratory fistulas: A report of 18 patients. Ann. Thorac. Surg. 37, 108-110.

Cottier, D.J., Carter, C.R., Smith, J.S., Anderson, J.R., 1997. The combination of laser recanalization and endoluminal intubation in the palliation of malignant dysphagia. J.R.Coll. Surg. Edinb. 2, 19-20. 
Currazoni, A., Bonavina, C., Segalin, A., 1999. Endoscopic palliation of oesophageal cancer: Results of a prospective comparison of Nd: YAG Lazer and ethanol injection. Eur. J. Surg. 165, 351-356.

Decker, P., Lippler, J., Decker, D., Hirner, A., 2001. Use of the Polyflex stent in the palliative therapy of esophageal carcinoma: Results in 14 cases and review of the literature. Surg. Endosc. 15, 1444-1447.

Domschke, W., Foerster, E.C., Matek, W., Rodl, W., 1990. Self-expanding mesh stent for esophageal cancer stenosis. Endosc. 22, $134-136$.

Dormann, A.J., Eisendrath, P., Wigginghaus, B., Huchzermeyer, H., 2003. Palliation of esophageal carcinoma with a new self-expanding plastic stent. Endoscopy. 35, 207-211.

Dorta, G., Binek, J., Blum, A.L., Bühler, H., Felley, C.P., Koelz, H.R., Lammer, F., Lang, C., Meier, R., Meyenberger, C., Meyer-Wyss, B., Michetti, P., Protiva, P., Scheurer, U., Weber, B., Wiesel, P., Vogel, S., 1997. Comparison between esophageal Wallstent and Ultraflex stents in the treatment of malignant stenoses of the esophagus and cardia. Endosc. 29, 149-154.

Ell, C., Riemann, J.F., Lux, G., Demling, L., 1986. Palliative laser treatment of malignant stenoses in the upper gastrointestinal tract. Endoscopy. 2126.

Eroğlu, A., Türkyılmaz, A., Aydın, Y., 2009. Özofagus hastalıklarında stent uygulamaları. Turkiye Klinikleri. J. Thor. Surg-Special Topics. 2, 95-99.

Eroglu, A., Turkyilmaz, A., Aydin, Y., Yekeler, E., Karaoglanoglu, N., 2009. Current management of esophageal perforation: 20 years experience. Dis. Esophagus. 22, 374-380.

Fleischer, D., Kesler. F., Haye, O., 1982. Endoscopic Nd: YAG laser therapy for carcinoma of the esophagus: A new palliative approach. Am. J. Surg. 143, 280-283.

Fleisher, D., 1987. A comparison of endoscopic laser therapy and BICAP tumor probe therapy for esophageal cancer. Am. J. Gastroenterol. 82, 608612.

Frenkel, J.L., Daly, B.D.T., Fernando, H.C., 2009. Palliative options and procedures. In Sugarbaker, D.J., Bueno, R., Krasna, M.J., Mentzer, S.J., Zellos, L., ed. Adult chest surgery, McGraw Hill Cos. 125-134

Giral, A., Kalaycı, C., 2002. Özofagusun kanser dışı hastalıklarında cerrahi tedavi. İç: Yüksel, M., Başoğlu, A. ed. Özofagus hastalıklarının tıbbi ve cerrahi tedavisi. 309-320.

Giuli, R., Gignoux, M., 1980. Treatment of carcinoma of the esophagus: Retrospective study of 2400 patients. Ann. Surg. 192, 44-52.

Golder, M., Tekkis, P.P., Kennedy, C., Lath, S., Toye, R., Steger, A.C., 2001. Chest pain following oesophageal stenting for malignant dysphagia. Clin. Radiol. 56, 202-205.

Heit, H.A., Johnson, L.F., Siegel, S.R., Boyce, H.W. Jr., 1978. Palliative dilation for dysphagia in esophageal carcinoma. Ann. Intern. Med. 89, 629631.

Hernandez, L.V., Jacobson, J.W., Haris, M.S., 2000. Comparison among the perforation rates of Maloney, balloon, and Savary dilation of esophageal strictures. Gastrointest. Endosc. 51, 460-462.

Homs, M.Y., Wahab, P.J., Kuipers, E.J., Steyerberg, E.W., Grool, T.A., Haringsma, J., Siersema, P.D., 2004. Esophageal stents with antireflux valve for tumors of the distal esophagus and gastric cardia: A randomized trial. Gastrointest. Endosc. 60, 695-702.

Horvath, O.P., Lukacs, L., 1996. Palliation of esophageal cancer: palliative resection and bypass surgery. Dis. Esophagus. 9, 117-122.

Hirai, T., Yamashita, Y., Mukaida, H., Kawano, K., Toge, T., Niimoto, M., Hattori, T., 1989. Bypass operation for advanced esophageal cancer an analysis of 93 cases. Jpn. J. Surg. 19, 182-188.

Homs, M.Y., Steyerberg, E.W., Eijkenboom, W.M., Tilanus, H.W., Stalpers, L.J., Bartelsman, J.F., van Lanschot, J.J., Wijrdeman, H.K., Mulder, C.J., Reinders, J.G., Boot, H., Aleman, B.M., Kuipers, E.J., Siersema, P.D., 2004. Single-dose brachytherapy versus metal stent placement for the palliation of dysphagia from oesophageal cancer: Multicentre randomised trial. Lancet. 364, 1497-1504.

Ilson, D.H., Saltz, L., Enzinger, P., Huang, Y., Kornblith, A., Gollub, M., O’Reilly, E., Schwartz, G., DeGroff, J., Gonzalez, G., Kelsen, D.P., 1999. Phase II trial of weekly irinotecan plus cisplatin in advanced esophageal cancer. J. Clin. Oncol. 17, 3270-3275.

Ilson, D.H., Forastiere, A., Arquette, M., Costa, F., Heelan, R., Huang, Y., Kelsen, D.P., 2000. A phase II trial of paclitaxel and cisplatin in patients with advanced carcinoma of the esophagus. Cancer J. 6, 316-323.

Iwasa, M., Ohmori, Y., Iwasa, Y., Yamamoto, A., Inoue, A., Maeda, H., Kume, M., Ogoshi, S., Nishioka, A., Ogawa, Y., Yoshida, S., 1998. Effect of multidisciplinary treatment with high dose rate intraluminal brachytherapy on survival in patients with unresectable esophageal cancer. Dig. Surg. $15,227-235$.

Javle, M., Ailawadhi, S., Yang, G.Y., Nwogu, C.E., Schiff, M.D., Nava, H.R., 2006. Palliation of malignant dysphagia in esophageal cancer: A literaturebased review. J. Support Oncol. 4, 365-379.

Jensen, D.M., Machicado, G., Randall, G., Tung, L.A., English-Zych, S., 1988. Comparison of low-power YAG laser and BICAP tumor probe for palliation of esophageal cancer strictures. Gastroenterology. 94, 1263-1270.

Johnston, J.H., Fleisher, D., Petrini, J., Nord, J., 1987. Palliative bipolar electrocoagulation therapy of obstructing esophageal cancer. Gastrointest. Endosc. 33, 349-353.

Kawasaki, R., Sano, A., Matsumoto, S., 2003. Long-term outcomes and complications of metallic stents for malignant esophageal stenoses. Kobe J. Med. Sci. 49, 133-142.

Kirschner, M., 1920. Ein neues verfahren der oesophagus plastik. Arch. Klin. Chir. 114, 606-663.

Knyrim, K., Wagner, H.J., Bethge, N., Keymling, M., Vakil, N., 1993. A controlled trial of an expansile metal stent for palliation of esophageal obstruction due to inoperable cancer. N. Engl. J. Med. 329, 1302-1307.

Korst, R.J., Ginsberg, R.J., 2005. Surgical Palliation of inoperable carcinoma of the esophagus. In Shields, T.W., LoCicero, J., Ponn, R.B., Rusch, V.W., ed. General Thoracic Surgery, vol 2, 6th ed. Philadelphia. Lippincott Williams and Wilkins 2313-2324.

Laasch, H.U., Marriott, A., Wilbraham, L., Tunnah, S., England, R.E., Martin, D.F., 2002. Effectiveness of open versus antireflux stents for palliation of distal esophageal carcinoma and prevention of symptomatic gastroesophageal reflux. Radiology. 225, 359 .

Litle, V.R., Luketich, J.D., Christie, N.A., Buenaventura, P.O., Alvelo-Rivera, M., McCaughan, J.S., Nguyen, N.T., Fernando, H.C., 2003. Photodynamic therapy as palliation for esophageal cancer: Experience in 215 patients. Ann. Thorac. Surg. 76, 1687-1693.

Lightdale, C.J., Heier, S.K., Marcon, N.E., McCaughan, J.S.Jr., Gerdes, H., Overholt, B.F., Sivak, M.V.Jr., Stiegmann, G.V., Nava, H.R., 1995. Photodynamic therapy with porfimer sodium versus thermal ablation therapy with Nd: YAG laser for palliation of esophageal cancer: A multicenter randomized trial. Gastrointest. Endosc. 42, 507-512.

Loizou, L.A., Grigg, D., Atkinson, M., Robertson, C., Bown, S.G., 1991. A prospective comparison of laser therapy and intubation in endoscopic palliation for malignant dysphagia. Gastroenterology. 100, 1303-1310.

Mayoral, W., Fleischer, D., Salcedo, J. 2000. Nonmalignant obstruction is a common problem with metal stents in the treatment of oesophageal cancer. Gastrointest. Endosc. 51, 556-559.

McCaughan, J.S.Jr., Ellison, E.C., Guy, J.T., Hicks, W.J., Jones, J.J., Laufman, L.R., May, E., Nims, T.A., Spiridonidis, C.H., Williams, T.E., 1996. Photodynamic therapy for esophageal malignancy; a prospective twelve-year study. Ann. Thorac. Surg. 62, 1005-1010. 
Meunier, B., Spiliopoulos, Y., Stasik, C., Lakéhal, M., Malledant, Y., Launois, B., 1996. Retrosternal bypass operation for unresectable squamous cell cancer of the esophagus. Ann. Thorac. Surg. 62, 373-377.

Minsky, B.D., Pajak, T.F., Ginsberg, R.J., Pisansky, T.M., Martenson, J., Komaki, R., Okawara, G., Rosenthal, S.A., Kelsen, D.P., 2002. INT 0123 (Radiation Therapy Oncology Group 94-05) phase III trial of combined-modality therapy for esophageal cancer: High-dose versus standard-dose radiation therapy. J. Clin. Oncol. 20, 1167-1174.

Murthy, S., Gonzalez-Stawinski, G.V., Rozas, M.S., Gildea, T.R., Dumot, J.A., 2007. Palliation of malignant aerodigestive fistulae with self-expanding metallic stents. Dis. Esophagus. 20, 386-389.

Mulle, J.M., Erasmi, J., Stelzner, M., Zieren, U., Pichlmaier, H., 1990. Surgical therapy of esophageal carcinoma. Br. J. Surg. $77,845-857$.

O’Rourke, I.C., Tiver, K., Bull, C., Gebski, V., Langlands, A.O., 1988. Swallowing performance after radiation therapy for carci $\neg$ noma of the esophagus. Cancer. 61, 2022-2026.

Overgaard, J., 1980. Simultaneous and sequential hyperthermia and radiation treatment of an experimental tumor and its surrounding normal tissue in vivo. Int. J. Radiat. Oncol. 6, 1507-1515.

Overgaard, J., Nielsen, O.S., Lindegaard, J.C., 1987. Biological basis for rational design of clinical treatment with combined hyperthermia and radiation. NATO ASI Ser. E. 127, 54-79.

Ökten, İ., 2003. Özofagus kanserleri. İç: Ökten, İ., Güngör, A., Gögüus Cerrahisi. Cilt 2, 1247-1226.

Okunaka, T., Kato, H., Conaka, C., Yamamoto, H., Bonaminio, A., Eckhauser, M.L., 1990. Photodynamic therapy of esophageal carcinoma. Surg. Endosc. $4,150-153$.

Rahmani, E.Y., Rex, D.K., Lehman, G.A., 1999. Z-stent for malignant esophageal obstruction. Gastrointest. Endosc. Clin. N. Am. 9, $395-402$.

Sabharwal, T., Hamady, M.S., Chui, S., Atkinson, S., Mason, R., Adam, A., 2003. A randomized prospective comparison of the Flamingo Wallstent and Ultraflex stent for palliation of dysphagia associated with lower third oesophageal carcinoma. Gut. 52, 922-926.

Sabharwal, T., Morales, J.P., Irani, F.G., Adam, A., 2005. Qualitiy improvoment guidelines for placement of esophageal stents. Cardiovasc. Inter. Rad. 28, 284-288.

Sander, R., Hagenmueller, F., Sander, C., Riess, G., Classen, M., 1991. Laser versus laser plus afterloading with iridium-192 in the palliative treatment of malignant stenosis of the esophagus: A prospective, randomized, and controlled study. Gastrointest. Endosc. 37, 433-440.

Schmassmann, A., Meyenberger, C., Knuchel, J., Binek, J., Lammer, F., Kleiner, B., Hürlimann, S., Inauen, W., Hammer, B., Scheurer, U., Halter, F., 1997. Self expandable metal stents in malignant esophageal obstruction: A comparison between two stent types. Am. J. Gastroenterol. 92, 400-406.

Shin, J.H., Song, H.Y., Ko, G.Y., Lim, J.O., Yoon, H.K., Sung, K.B., 2004. Esophagorespiratory fistula: Long-term results of palliative treatment with covered expandable metallic stents in 61 patients. Radiology. 232, 252-259.

Shim, C.S., Jung, I.S., Cheon, Y.K., Ryu, C.B., Hong, S.J., Kim, J.O., Cho, J.Y., Lee, J.S., Lee, M.S., Kim, B.S., 2005. Management of malignant stricture of the esophagogastric junction with a newly designed self-expanding metal stent with an antireflux mechanism. Endosc. 37, 335-339.

Siersema, P.D., Hop, W.C., van Blankenstein, M., van Tilburg, A.J., Bac, D.J., Homs, M.Y., Kuipers, E.J., 2001. A Comparison of 3 types of covered metal stents for the palliation of patients with dysphagia caused by esophagogastric carcinoma: A prospective randomized study. Gastrointest. Endosc. 54, 145-153.

Siersema, P.D., Hop, W.C., Dees, J., Tilanus, H.W., van Blankenstein, M., 1998. Coated self-expanding metal stents versus latex prostheses for esophagogastric cancer with special reference to prior radiation and chemotherapy: A controlled, prospective study. Gastrointest. Endosc. 47, 113-120.

Spencer, G.M., Thorpe, S.M., Blackman, G.M., Solano, J., Tobias, J.S., Lovat, L.B., Bown, S.G., 2002. Laser augmented by brachytherapy versus laser alone in the palliation of adenocarcinoma of the oesophagus and cardia: A randomised study. Gut. 50, 224-227.

Spiridonidis, C.H., Laufman, L.R., Jones, J., Rhodes, V.A., Wallace, K., Nicol, S., 1998. Phase I study of docetaxel dose escalation in combination with fixed weekly gemcitabine in patients with advanced malignancies. J. Clin. Oncol. 16, 3866-3873.

Song, H.Y., Jung, H.Y., Park, S.I., Kim, S.B., Lee, D.H., Kang, S.G., II Min, Y., 2000. Covered retrievable expandable nitinol stents in patients with benign esophageal strictures: Initial experience. Radiology. 217, 551-557.

Stoller, J.L., Brumwell, M.L., 1984. Palliation after operation and after radiotherapy for cancer of the esophagus. Can. J. Surg. 27, 491-495.

Sur, R.K., Donde, B., Levin, V.C., Mannell, A., 1998. Fractionated high dose rate intraluminal brachytherapy in palliation of advanced esophageal cancer. Int. J. Radiat. Oncol. 40, 447-453.

Tan, B.S., Mason, R.C., Adam, A., 1996. Minimally invasive therapy for advanced oesophageal malignancy. Clin. Radiol. 51, 828-836.

Tebbutt, N.C., Norman, A., Cunningham, D., Iveson, T., Seymour, M., Hickish, T., Harper, P., Maisey, N., Mochlinski, K., Prior, Y., Hill, M., 2002. A multicentre, randomised phase III trial comparing protracted venous infusion (PVI) 5-fluorouracil (5-FU) with PVI 5-FU plus mitomycin C in patients with inoperable oesophago-gastric cancer. Ann. Oncol. 13, 1568-1575.

Therasse, E., Oliva, V.L., Lafontaine, E., Perreault, P., Giroux, M.F., Soulez, G., 2003. Balloon dilation and stent placement for esophageal lesions: Indications, methods, and results. Radiographics. 23, 89-105.

Tomaselli, F., Maier, A., Sankin, O., Woltsche, M., Pinter, H., Smolle-Jüttner, F.M., 2001. Successful endoscopical sealing of malignant esophageotracheal fistulae by using a covered self-expandable stenting system. Eur. J. Cardiothorac. Surg. 20, 734-738.

Turhal, N.S., 2002. Özofagus kanserinde kemoterapi ve kemoradyoterapi uygulamaları. Özofagus hastalıklarının tıbbi ve cerrahi tedavisi. $321-328$.

Turkyilmaz,, A., Eroglu, A., Aydin, Y., Kurt, A., Bilen, Y., Karaoglanoglu, N., 2010. Complications of metallic stent placement in malignant esophageal stricture and their management. Surg. Laparo. Endo. Per. 20, 10-15.

Turkyilmaz, A., Eroglu, A., Aydin, Y., Tekinbas, C., Muharrem Erol, M., Karaoglanoglu, N., 2009. The management of esophagogastric anastomotic leak after esophagectomy for esophageal carcinoma. Dis. Esophagus. 22, 119-26.

Turkyilmaz, A., Aydin, Y., Eroglu, A., Bilen, Y., Karaoglanoglu, N., 2009. Palliative management of esophagorespiratory fistula in esophageal malignancy. Surg. Laparo. Endo. Per. 19, 364-367.

Watkinson, A., Ellul, J., Entwisle, K., Farrugia, M., Mason, R., Adam, A., 1995. Oesophageal carcinoma: Initial results with covered self expanding endoprostheses. Radiology. 195, 821-827.

Wengrower, D., Fiorini, A., Valero, J., Waldbaum, C., Chopita, N., Landoni, N., Judchack, S., Goldin, E., 1988. EsophaCoil: long-term results in 81 patients. Gastrointest. Endosc. 48, 376-382.

Wang, M.Q., Sze, D.Y., Wang, Z.P., Wang, Z.Q., Gao, Y.A., Dake, M.D., 2001. Delayed complications after esophageal stent placement for treatment of malignant esophageal obstructions and esophagorespiratory fistulas. J. Vasc. Interv. Radiol. 12, 465-474.

Verschuur, E.M., Kuipers, E.J., Siersema, P.D., 2007. Esophageal stents for malignant strictures close to the upper esophagealsphincter. Gastrointest. Endosc. 66, 1082-1090. 